DEPÓSITO LEGAL ZU2020000153

Esta publicación científica en formato digital

es continuidad de la revista impresa

ISSN 0041-8811

E-ISSN 2665-0428

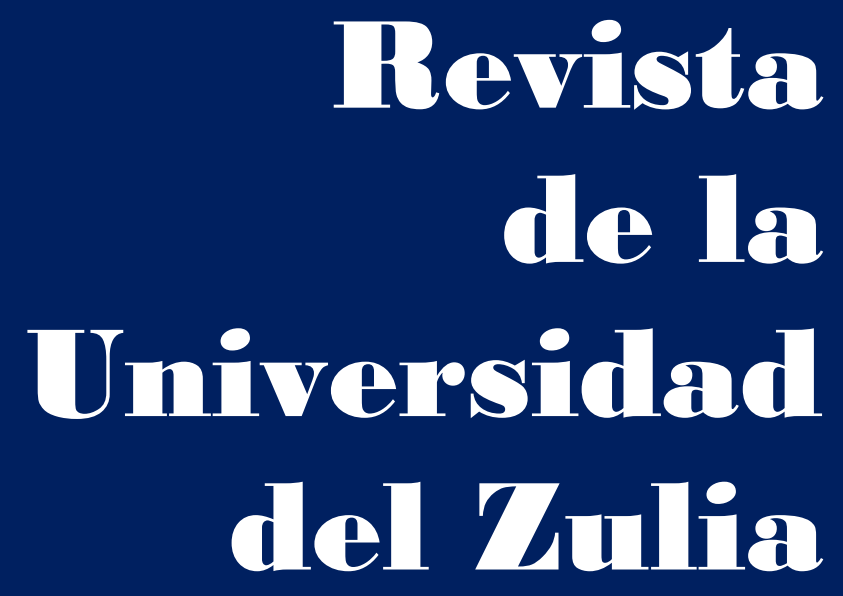

Fundada en 1947

por el Dr. Jesús Emrique Lossada

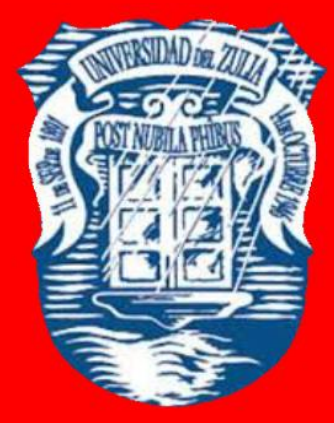

Ciencias

Sociales

y Arte

Año $12 \quad N^{\circ} 34$

Septiembre - Diciembre 2021

Tercera Época

Maracaibo-Veneruela 


\title{
Yakut Ritual Dance "Pattern": concepts of life and death
}

\section{Angelina Grigorevna Lukina *}

\begin{abstract}
This article reviews the Yakut ritual dance called "Pattern" which is connected to archaic funeral rite and to the concepts of life and death intrinsic to Yakut culture. The purpose of this article is to find in this dance symbolic and image-bearing elements indicating major concepts in the Yakut consciousness - concepts of life and death; to show the exceptional value and significance of "life" constant in ethnos consciousness; to address the Yakut ritual dance "Pattern" as one of the ways to display life in dance images; and, analysing the meaning of dance structure and choreography, to demonstrate transformation of "death" into a new quality, a symbol of "life". The present study reveals the meaning of ritual movements by which death "changes into" life. The methodological basis of the article consists of the analysis of bibliographic sources on Yakut ritual dance. The content and meaning of the dance movements are identical to the worldviews of the ancient Turkish people and their concepts of life and death.
\end{abstract}

KEY WORDS: folk art; Arctic cultures; traditional dance; rites; symbols.

* Doctor of Art History, Professor of the Department of Choreography, Arctic State Institute of Arts and Culture, Russia. ORCID: https://orcid.org/0000-0002-6004-3075. E-mail: angelinalucinal@mail.ru 


\section{Danza ritual yakuto "Patrón”: conceptos de vida y muerte}

RESUMEN

Este artículo revisa la danza ritual yakuto llamada "Patrón", que está conectada con el rito funerario arcaico y con los conceptos de vida y muerte intrínsecos a la cultura yakuto. El propósito de este artículo es encontrar en esta danza elementos simbólicos que contienen imágenes que indican los principales conceptos en la conciencia yakuto: conceptos de vida y muerte; mostrar el valor excepcional y el significado de la "vida" constante en la conciencia etnos; abordar la danza ritual yakuto "Patrón" como una de las formas de mostrar la vida en las imágenes de la danza; y, analizar el significado de la estructura de la danza y la coreografía, para demostrar la transformación de la "muerte" en una nueva cualidad, un símbolo de "vida". El presente estudio revela el significado de los movimientos rituales por los cuales la muerte "se transforma" en la vida. La base metodológica del artículo consiste en el análisis de fuentes bibliográficas sobre danza ritual yakuto. El contenido y el significado de los movimientos de la danza son idénticos a las cosmovisiones del antiguo pueblo turco y a sus conceptos de vida y muerte.

PALABRAS CLAVE: arte popular; Culturas árticas; danza tradicional; ritos; símbolos.

\section{Introduction}

The article aims to discover concepts of life and death as parts of the ancient funeral rites in the Yakut ritual dance "Pattern", as well as to introduce researchers, ethnographists, folklore specialists and those interested in traditional culture of the people of the world, to a unique example of traditional choreography of the Yakuts, the northern Turkic people.

The article studies the choreography language and the structure of the Yakut ritual dance "Pattern" which are tied to the concepts of life and death. It performs a semantic analysis of ritual movements which serve as means of transforming "death" into "life".

This article reviews the Yakut ritual dance called "Pattern" which is connected to archaic funeral rite and to the concepts of life and death intrinsic to Yakut culture. The present study is the first to analyze choreography language and structure of the Yakut ritual dance "Pattern" in order to ascertain concepts of life and death that can be traced back to ancient Yakut rites. The article reveals the defining characteristics of choreography language and dance composition, and performs a semantic analysis of ritual movements that display the signs of key concepts of life and death. It analyses the ideas, images and features of the Yakut ritual dance "Pattern" in the context of Yakut worldviews, religious views and 
traditional values. Even though the dance is connected to the ritual of funeral and remembrance, the "Pattern" dance is treated as a dance of life celebration. The article introduces the unique plot and ornamental movements of the Yakut ritual dance "Pattern" into scholarly discourse. It places emphasis on significance and value of the dance as an extraordinary piece of traditional Yakut culture spearheading the idea of life triumphing over death. There are two words for the same ethnic group in this article: "Yakut", ("Yakuts" in plural) - which is the official name - and "Sakha", the word the Yakuts use to call themselves.

The relevance of this article stems from the need to preserve archaic examples of the Yakut dance folklore that express universal ideas of life and survival. The relevance is also based on the necessity to introduce into scholarly discourse the vision and the mythos of life and death concepts in the Yakut dance folklore. Functioning of traditional values and key concepts for life and death phenomena are also important for modern art as patterns for organising the lasting values in figurative language of folk art.

Yakut shamanism, heroic epics, mythology and legends examine the themes of life and death. The philosophical problem of life and death and their balance is embodied in various folk art genres. This theme is developed in different aspects via mediums of expressions pertaining to certain types of folk art. Traditional dance culture of the Yakut people uses metaphor to conceptualize the issues of life and death. Folk art emphasises the celebration of life, prosperity, abundance, happiness, joy. In folk art, optimistic and humanistic works outweigh the death theme. Yet the ever-present idea of death has always exercised the people's minds. Traditional and ritual dances that create visual images can sometimes offer interesting and even surprising takes on the themes of life and death. For the Yakuts, life and death were connected to the three-part world idea, widespread among many Turkic peoples. Yakut worldviews and religious beliefs hinge in this idea; the interrelation between the three worlds is the foundation for the spiritual world of the Yakut people. All main points of traditional Yakut culture, including the questions of life and death, are built upon the threepart world concept. In the Middle world, - called Orto Doidu, - populated by the Aiyy people, life triumphed. Allaraa Doidu, or the Lower world, was connected to death and all its tragic and aggressive aspects. As the three-part world concept encompassed the entirety of the Yakuts spiritual world, it is impossible to find a folk art genre, which would not use the said concept as its base. Yakut mythology thoroughly develops the idea of three 
REVISTA DE LA UNIVERSIDAD DEL ZULIA. 3época. Año $12 \mathrm{~N}^{\circ}$ 34, 2021

Angelina Grigorevna Lukina // Yakut Ritual Dance "Pattern”: concepts of life and death, 604-630

DOI: http://dx.doi.org/10.46925//rdluz.34.33

interconnected worlds.

The present article looks at a dance as a means of demonstrating certain attitude to life and death.

1. Theoretical and methodological aspects

The methodology for studying traditional culture involves studying the works of researchers who have recorded unique materials of Yakut cultural heritage. The Yakuts are the northernmost Turkic-speaking population. Their historical fate, fraught with difficulties, influenced their traditional culture and development of certain characteristic of various folk art types, including traditional dances. Choreography language of the Yakut dances differs from traditional art of dancing of indigenous small-numbered peoples of the North. Analysis of traditional Yakut dances shows features common to dances of Turkic-speaking peoples. The majority of elements in the "Pattern" dance are connected to the ancient Turkic foundation. The dance has a prominent eastern tone. In this regard of particular interest are archaic ritual complex, worldview, religious beliefs, system of deep-seated essential values. The article uses methods based on a comprehensive and systematic analysis of traditional dance culture. The methodological basis of the theoretical aspect of the study were the works of Russian researchers of ethnography, folklore, art history, ethnic choreography. The main methodological framework for reviewing the principles of traditional culture can be found in the works that belong to the scholars of folk art, folklore, archaeology, traditional art, and Northern studies, such as: J.G. Gmelin, J.J. Lindenau, R. K Maack, A.F. Middendorff, I.A. Khudyakov, W.L. Sieroszewski, E.K. Piekarski, N.Ya. Bichurin, V.I. Jochelson, E.B. Tylor, L.S. Vygotsky, V.Ya. Propp, B.N. Putilov, V.I. Pukhov, N.V. Emelyanov, A.S. Kargin, , E.S. Novik, A.P. Okladnikov, M.M. Nosov, G.P. Sokolova, D.S. Dugarov, E.E. Alekseev, and others.

The methodology base includes the works of researchers who studied semantic and functional analysis methods as well as symbolic nature of traditional culture, such as L. LévyBruhl, A.D. Avdeev, C. Lévi-Strauss, Yu.M. Lotman, M. Eliade, Ye.M. Meletinsky, S.E. Malov, V.M. Zhirmunsky, V.B. Iordansly, A.K. Baiburin, N.A. Alekseev, A.I. Gogolev, and others.

In the study of traditional Yakut choreography, the works of the following Yakut folklorists carry weight: A.E. Kulakovsky, G.V. Ksenofontov, P.A. Oyunsky, A.A. Savvin, G.U. Ergis, and others. The present article employs the traditional choreography studies by 
REVISTA DE LA UNIVERSIDAD DEL ZULIA. 3época. Año $12 \mathrm{~N}^{\circ}$ 34, 2021 Angelina Grigorevna Lukina // Yakut Ritual Dance "Pattern”: concepts of life and death, 604-630 DOI: http://dx.doi.org/10.46925//rdluz.34.33

scholars and members of traditional Yakut culture, such as S.A. Zverev-Kyyl Uola, I.D. Izbekov-Uustakh. The works of the first scholar of traditional choreography of the peoples of the North M.Ya. Zhornitskaya are of special interest.

The folk choreography researchers that have developed theoretical and practical aspects of traditional choreography of the peoples of Russia are N.S. Nadezhdina, T.A. Ustinova, S.S. Lisitsian, Yu.M. Churko, E.A. Koroleva, V.V. Romm, T.S. Tkachenko, V.A. Teider, V.I. Uralskaya, A.G. Lukina, R.V. Kenzikeeva, and others.

In the study of dance culture of particular interest are the works of researchers of dance folklore of the peoples of the North, Siberia and the Far East: M.Ya. Zhornitskaya, T.F. Petrova-Bytova, S.F. Karabanova, N.S. Kaplin, V.N. Nilov, A.A. Petrov, Ye.A. Rultyneut, N.A Struchkova, L.E. Timasheva, and others.

In order to develop the research, the results of the development of this topic by Yakut researchers were analyzed. A comparative analysis of dances in the context of Yakut ritual complex was carried out. This topic was developed by M.Ya. Zhornitskaya, researcher of the dance culture of Northern peoples, in her monographs "Folk dances of Yakutia" (Moscow, "Nauka", 1960); M.Ya. Zhornitskaya "Folk choreographic art of indigenous population of the North - East Siberia" (Moscow, "Nauka", 1983). M. Ya. Zhornitskaya studied dances staged by S. A. Zverev-Kyyl Uola, an expert and bearer of traditional Yakut dance culture, such as "Pattern", "Selberece", "White Crane Dance". The dances of S. A. Zverev were based on the dance folklore of the Yakuts and were closely connected with the world views and beliefs of the Yakuts. The topic of ritual and ceremonial dances of the Yakuts was developed by the researcher N.A. Struchkova, in particular the mythological and ritual foundations of the Yakut circular dance "osuokhai", the kinetic culture of the Yakuts, including the "Pattern" dance. Her research in the elements of non-verbal communication is close to the author of this article in terms of identifying the ritual behavior of Yakuts in establishing communicative relations with the outside world. N.A. Struchkova writes that "through the mythological traditional worldview of Yakuts, the legend helps to reveal the semantics of human movement plasticity. Ritual walking in a circle is indeed a symbol of motifs of enclosure, purification and creation of a new "pure space". This also applies to the "Pattern" dance, which is performed in a circle and associated with the motif of purification". (N.A. Struchkova. Olonkho and foundations of kinetic culture of the Sakha People - Novosibirsk, 
REVISTA DE LA UNIVERSIDAD DEL ZULIA. 3época. Año $12 \mathrm{~N}^{\circ}$ 34, 2021

Angelina Grigorevna Lukina // Yakut Ritual Dance "Pattern”: concepts of life and death, 604-630

DOI: http://dx.doi.org/10.46925//rdluz.34.33

"Nauka", 2008). N.A. Struchkova writes that the circle dance is a part of the ritual of the vertical plan in the funeral rites. The main value of the circle is a connection of two oppositions - "our own world" with "other world" (Struchkova. Formation of the kinetic component in ritual practice. - St. Petersburg, Publishing house of Saint Petersburg university, 2005).

\section{Results and discussion}

According to the Yakut mythology, there exist three worlds: the Upper world, or heavens, the Middle world, where humans live, and the Lower world, or the underworld (Ergis, 1974).

The philosophy of traditional concepts and traditional Yakut culture based on interplay, interdependence and interrelationship of concepts of life and death. Connection and balance between these two concepts were what traditional concepts strived to fashion. Aal Luuk Mas, that is, the world tree, serves as an axis connecting the three worlds. The cosmology model of three worlds connected to each other is universally widespread. The idea of a three-part world represents a typological concept, common in mythologies around the world, which pertains to a rather archaic layer of beliefs every so often connected to shamanism (Bongard-Levin, 1980). The idea of a three-part world is deeply engrained in all types and genres of folk art, particularly in patterns of visual arts such as ritual choreography. The belief in establishing a connection between three worlds lies at the heart of three-part concept (Lukina, Doktorova, 2013).

Mythological thinking that gave birth to this concept is in and of itself close to imagery and figurality found in dances. Visual images for such fundamental concepts like life and death were created by means of imaginary and evocative dance language. Archaic images of Yakut ritual and ceremonial dances uncover the three-part world concept through semantic content, plastique and visual symbols, poses and pas, spatial dance composition and structure. Mediums of choreographic expressions reveal the heart of the three-part universe. Choreographic text as one of the most ancient ways of expressing thoughts and feelings, which is comprised of movements, ritual gestures, poses, pantomime and facial expressions, reflected and visualised key concepts of life and death.

In traditional Yakut dances, the meaning behind the main movements follows the idea of mastering horizontal and vertical space, and the actualization of philosophical concepts of 
REVISTA DE LA UNIVERSIDAD DEL ZULIA. $3^{a}$ época. Año $12 \mathrm{~N}^{\circ}$ 34, 2021 Angelina Grigorevna Lukina // Yakut Ritual Dance "Pattern": concepts of life and death, 604-630 DOI: http://dx.doi.org/10.46925//rdluz.34.33

life and death. Three-part world concept serves as the foundation for such Yakut dances as traditional circle dance "Osuokhay", ritual dance "Bitii", ritual dance "Pattern", ceremonial dance "Warrior's initiation", dance "Algys" ("The Blessing dance"), etc. Traditional Yakut dances developed based on the religious beliefs and shamanistic worldviews, and they contain key concepts and meanings the people hold close. The significance of these dances, their structure and their images allow them to act as bridge for the three worlds. Vertically and horizontally oriented traditional and ritual dances functioned as a model for making connection between the three worlds. In this regard, the Yakut ritual dances were archaic symbols for connecting rational and irrational. They also were a reference pattern for moving between the worlds. This connection between the three worlds is evident in the ritual Yakut dance "Pattern". Traditional Yakut art acknowledges a possibility of an "open road" between the three worlds, and this means that these worlds are interconnected. The confirmation can be found in how the spatial structure of traditional Yakut dances is oriented both vertically and horizontally. In Yakut ritual dances, when dancers move in a circle, it means reaching a sacred world. This is found in the final part of the "Pattern" dance, when dancers send the soul of the dead girl into the otherworld and thus separate her from the living. This symbolic kinetic code of circle movements can be seen the majority of traditional Yakut dances.

The "Pattern" dance, which dates back to the antiquity, is one of the oldest and most meaningful dances in the traditional Yakut dance culture. This dance provides insight into philosophic nature of existence, into interactions and conflicts between life and death, into transcendental barrier one crosses when leaving their world forever. Unfortunately, the original name of this dance has been lost, along with many other elements of traditional Yakut culture. Yet this fact does not diminish the meaning of the "Pattern" dance that is closely connected to beliefs, worldviews and religion of the Sakha people. The "Pattern" dance holds a special place in the traditional Yakut culture as a dance tied to an archaic and conservative event - a funeral rite. The dance is focused on the ideas of spiritual life of the Yakuts, mystic experiences and key concepts of life and death. The Middle world, where humans live, is a world of life, prosperity and happiness. The Lower world is associated with death, tragedy and aggression. The "Pattern" dance, using ritual movements, poses and gestures, reveals the rhythm of the alien world where death reigns, and the rhythm of life and nature, the part of which humans consider themselves. 
REVISTA DE LA UNIVERSIDAD DEL ZULIA. 3época. Año $12 \mathrm{~N}^{\circ}$ 34, 2021 Angelina Grigorevna Lukina // Yakut Ritual Dance "Pattern”: concepts of life and death, 604-630 DOI: http://dx.doi.org/10.46925//rdluz.34.33

The dance tells of a connection between life and death by replicating it and the series of actions that transport a person from life into the otherworld. At first sight, the way ancient Yakuts perceived the phenomenon of death might seem paradoxical. While the "Pattern" dance speaks of one's passing, it actually celebrates life and the joy of living. The dance has a deeply humanistic meaning that prevails over despair and tragedy of death. It contains a story about how, when faced with death, a dying person can receive a kind of compensation for the life they did not get to enjoy to the fullest, a compensation in the form of dance. In other words, this person gets a parting gift in the form of choreographic images that recreate their life in a ritual dance. The "Pattern" is a dance of life and hope, not of grief and sadness. Exaggeratedly upbeat and optimistic, it strives to perpetuate life and to expand its limits. The dance makes it possible to transform the idea of death into the idea of life.

The relevance of death, based on ancient Yakut funeral rites, changes into the relevance of life in the "Pattern" dance. Ultimately, the dance actualizes not death but life, continuing and infinite, despite the fact that the plot of the dance is related to a very conservative funeral rite.

S.A. Zverev-Kyyl Uola, poet and choreographer, singer-improvisator, directing singer in Osuokhay circle dance, Olonkho narrator, keeper of traditional Yakut culture and its scholar, managed to restore the "Pattern" dance in 1957. He reconstructed and put into action a scenic interpretation of this ancien story. To stage the dance, he drew on a legend from Suntarsky district. The legend speaks of a famous udagan called Chypchakhaidaakh. This legend is widespread in Yakutia, and several variants of it can be found in archives.

Folklorist A. Savvin in Suntarsky district recorded funeral rites of the Yakuts in 1938 according to information provided by M.V. Vasiliev and S.A. Zverev, residents of Tyubyaysky nasleg in Suntarky district. In Ust-Aldansky district A. Savvin recorded the rite of similar nature called "Былыргы комуу" (bylyrgy komuu), which means "Ancient funeral" (Yakutsk National Centre, 1936-1941). Such rite existed in other regions of Yakutia as well; archives offer information on an ancient rite where underage deceased persons were buried repeatedly.

Many districts of Yakutia seem to have practised this rite. It was observed rigidly when a person deceased was the only child in the family and died before coming of age.

Funeral rites are connected to religious activities performed in the following situation: 
REVISTA DE LA UNIVERSIDAD DEL ZULIA. 3época. Año $12 \mathrm{~N}^{\circ}$ 34, 2021 Angelina Grigorevna Lukina // Yakut Ritual Dance "Pattern”: concepts of life and death, 604-630 DOI: http://dx.doi.org/10.46925//rdluz.34.33

1. The custom was performed as a farewell to family and friends. Deceased was sat down to the table and treated to various dishes.

2. The custom was perceived as a form of recompense paid to one who died too early the deceased was given that which they were supposed to experience (marriage, celebrations, and joys of life) but did not get to because of sudden death.

3. Deceased was offered an opportunity to take a last look at their home grounds. For example, in the "Pattern" dance, before the dead girl is buried, she, wearing her best clothes, is taken by the armpits by other dancers and is carried around the place where she used to live. The horse that would deliver the deceased to the realm of the dead was buried too. Before the horse was buried, a rider mounted it and rode several times around the place where the deceased used to live.

4. The custom where the dead girl would be held on both sides by young boys and girls who would put food into her hands and then treat her relatives to that food, so that it would seem as if the girl was offering food to her relatives.

According to the legend, in Tyubyaysky nasleg, in a locality called Turannakh famous udagan Chypchakhaidaakh organised a "farewell" ceremony due to the untimely passing of her underage daughter. During the ceremony all the ancient customs were observed very strictly. The legend says that the udagan performed her shamanistic ritual for seven days and seven nights without rest, all to restore her daughter to life. There was a belief that powerful shamans and udagans could shamanise for nine full days to bring dead back to life and to cure hopelessly ill people. Yakut epic has the following words: "олбут киһини ондотор буоларбыт, умсубут киһини уодас ойутарбыт" (olbut kihini ondotor buolarbyt, umusubut kihini uodas oiutarbyt), "улуһуйэн туойдахпына олбутэ ус сыл буолбут киһини ондотор бэйэм этим" (uluhuien tuoidakhpyna olbute us syl buolbut kihini ondotor beiem etim), i. e. "revived the deceased, raised the departed, with their toyuk-song three years dead man brought back to life." However, in the Suntar legend, Chychakhaidakh could not revive her daughter, and so she arranged a great funeral. During the funeral, udagan danced the "Pattern" dance, accompanied by seven "pure", "immaculate" young girls and boys - bitisiits, sometimes called sing-along dancers. The udagan, holding a shaman's drum each hand, would stand in front of bitisiits and show them dance movements that they would repeat. Lead by the udagan, these boys and girls would use ritual poses, movements and 
REVISTA DE LA UNIVERSIDAD DEL ZULIA. 3época. Año $12 \mathrm{~N}^{\circ}$ 34, 2021

Angelina Grigorevna Lukina // Yakut Ritual Dance "Pattern”: concepts of life and death, 604-630

DOI: http://dx.doi.org/10.46925//rdluz.34.33

gestures to create in real time the images of the dead girl's happy life, so that she would not depart aggrieved with her lot and would not pose danger to the living.

The legend says that the udagan performed her daughter's reburials for three years in a row. Each time she organised a ceremony that was similar to Ysyakh celebration. And each time "pure" and "immaculate" young boys and girls, bitisiits, danced with her. The legend recorded by A. Savvin has it that bitisiits danced with the dead girl while holding her on both sides and moving her hands so that they made pattern gestures. The dancers themselves also made these gestures. The dance served as a means to give to the untimely deceased girl the joy she was due on her wedding day.

It may be assumed that in the past bitisiits performed this dance in presence of the dead person, and sometimes even with the "participation" of the dead body. However, it may be more reasonable to assume that her living friend played the dead bride part.

The "Pattern" dance is a multifunctional one. On one hand, it is a talisman, and as such, it has a protective function. The dance protected the living from the dead; it created a barrier that did not allow the dead to enter the circle of the living. That way, dancers formed a mythical space safeguarded from the evil spirits. The circle, drawn by dancing boys and girls, separates life from death and emphasises their conflict and contradiction. Mundane and sacred meet in this dance. Circle and straight lines represented an open road to Heavens where "kut", the girl's soul, goes after her death. Soul's ascension to heaves is connected to entering sacred spaces (Mircea Eliade, 1999). A circle is a mythical space.

On the other hand, the "Pattern" dance is a "recompense" paid to the dead girl for the life she did not get to live so that she would not pose danger to the living. Life and death meet in this dance. In the end, life prevails in the dance, life and the joy of living. Every happy occurrence that should have happened in the life of the udagan's daughter is mediated through the original movements of the dance. The ritual poses and gestures recreate happy moments of one's life. The "Pattern" dance has a complex kinetic text. Each movement has a profound meaning and serves as a sign. Combination of movements creates kinetic text in which signs and symbols tell the story of the girl's life. Each gesture holds significance and can be read. The story is told through combinations of dance elements, poses and gestures.

At first glimpse, the dance may seem to be telling a tale that only has happy moments. But it is important to bear in mind that the dance is also about saying goodbye to the young 
girl that departed this life. The dance does not overstress this part and highlights joyful, optimistic moments. The performance of this dance is exaggeratedly upbeat and elated. Therefore, the "Pattern" dance reflects the philosophy of persisting life with its sunny sides, prosperity, hope and the happiest moments of existence. It emphasises the idea of life triumphing over death. Dancers perform this joyful dance devotedly, trying to oppose the inevitability of departure from life. At the same time, the dance contains dramatic elements pertaining to human life. Pas and symbolic movements of the dance embody the joy of life, the drive for it and its celebration, while keeping some notes of ruminations on its inevitable end. This is what the "Pattern" dance philosophy is about. The dance concentrates seemingly incompatible concepts of life and death as contradicting phenomena. The "Pattern" dance is definitely a dance of the circle of life, even with the presence of tragic moments related to the plot.

An archaic custom of bidding farewell to young girls who dies before coming of age and getting married is close to worship of noble maidens that was practised by the Yakuts. There was an exceptional attitude displayed towards noblemen daughters who died old enough to be considered brides but yet unmarried. If a deceased girl were the only daughter, the favourite child, blessed with beauty, then her parents would call for a shaman and ask him to perform a ritual of implanting the girl's soul into a special doll made of birch bark. Such a doll was called "бах танара" (bakh tanara), "divine maiden", or "туос танара" (tuos tanara), "birch bark deity" (Ksenofontov). Its purpose was to immortalize an image of an untimely deceased person. Therefore, it is of no coincidence that the dancers created with their hand movements that represent birch bark vessels. The "Pattern" dance includes an original movement known as «mуос uhит ойуyma» (tuos uhum oiuta), or "birch bark vessel pattern". The dancers draw this pattern using hand gestures. The existence of movements of this nature indicates that the dance was performed in situations connected to funeral rites. As far as is known, the Yakuts quite often used birch bark as a material for their funerary structures. It is of particular interest that those birch bark sheets that were used in a funeral rite were usually decorated with various grooved ornaments (Bravina, 1996).

A dead body would often be wrapped in a canvas made of birch bark or covered with ornamental birch bark sheets. Patterned birch bark was a ritual attribute (Konstantinov, 1971). 
REVISTA DE LA UNIVERSIDAD DEL ZULIA. 3época. Año $12 \mathrm{~N}^{\circ}$ 34, 2021 Angelina Grigorevna Lukina // Yakut Ritual Dance "Pattern”: concepts of life and death, 604-630 DOI: http://dx.doi.org/10.46925//rdluz.34.33

The "Pattern" dance function was to please the deceased. Once the dead girl would receive their reward in the form of a dance, she would not show displeasure and bother the living. By using the dance, udagan and bitisiits helped the dead girl to leave the Middle world peacefully and to reach the otherworld. With this energetic dance, they separated "кym" (kut) - the dead girl's soul from «kym» (kut) - the souls of the living. The protective function of the "Pattern" dance is clearly in evidence. In this case, the exaggeratedly upbeat dance movements served as one of precautionary measures against evil spirits. Vigour and temper of the dancers were supposed to repel evil spirits. Pattern hand movements, performed synchronously and cyclically, were supposed to prevent evil spirits from getting into the living space. "Pure" girls and boys lead by the udagan were to act as an impenetrable barrier against evil spirits. This protective function was typical for archaic dances of ritual nature.

As mentioned above, the "Pattern" dance by S.A. Zverev is similar in content in composition to the ceremonial celebration of Ysyakh. It is known that in the old days the Yakuts would commemorate the passing of their ancestors. The ancient form of Ysyakh can be traced back to funeral and commemorative traditions. Ancestor worship motive is one the most prioritized motives in Ysyakh. In a more archaic variant of Ysyakh, people would pay respects and obeisance to their ancestors (Klark, 1864). A grand scale ancient ceremony of Ysyakh is the main national celebration of worship of ancestors and deities-ayii. Crucial role belonged to algyschyt - priest performing the ritual blessing ceremony. The priest was accompanied by bitisiits, sacred "sing-along dancers". Nine "pure" young boys and eight "immaculate" young girls helped the priest in the rituals. Archaic Yakut heroic epic tales mention these sacred dancers, bitisiits. They serve as an important symbol that has ties to the ideas of beauty, purity and dignity. In Yakut heroic epic, nine young boys bitisiits were compared to tall male white cranes, and eight young girls bitisiits were compared to female white cranes (Kyys Debiliye, 1993). The sacred number nine associated with harmony and perfection, while number eight was connected to infinity and perpetuity of life. Nine boys like free-flying cranes and eight girls like brilliant white cranes symbolised purity, innocence, peak of vital energy. Bitisiits-dancers took part not only in life cycle rites, but also in archaic funeral rites. This suggests that bitisiits participated in crucial Yakut rituals.

Pure, immaculate boys and girls danced in the "Pattern" dance as well as in Ysyakh ceremony. They helped the udagan to see her dead daughter to her final journey, and they 
REVISTA DE LA UNIVERSIDAD DEL ZULIA. 3época. Año $12 \mathrm{~N}^{\circ}$ 34, 2021 Angelina Grigorevna Lukina // Yakut Ritual Dance "Pattern”: concepts of life and death, 604-630 DOI: http://dx.doi.org/10.46925//rdluz.34.33

embodied a certain divine power. Only their pure souls and their good intentions could lift «кym» (kut), i. e. the girl's soul all the way to the otherworld. The lifting of the girl's soul «Kym» (kut) - has a very clear representation in the images and composition of the "Pattern" dance.

The dance reflects the most archaic meaning of the Ysyakh ceremony, which combines the ideas of death and rebirth. Ysyakh was a multifunctional ceremony that, due to its symbolical nature, captured numerous essential ideas of the people. One of the earliest ideas embedded in Ysyakh is the idea of death and rebirth. The Ysyakh ceremony has a double symbolic meaning: renewal follows the parting of the past, before every rebirth comes death. When one thing ends, another thing begins. According to the legends, the Ysyakh ceremony was preceded by the death of Omogoi's favourite daughter. Omogoi had a daughter that was not very beautiful and was treated almost like a slave. Ellei, who would become a forefather of the Yakuts, chose this girl his wife. Omogoi and his wife were not happy with Ellei's choice. The legend says that the other seven (or two, according to other variants) daughters strangled themselves to death. The other variant of the legend has it that Omogoi's favourite daughter went missing. It is believed that she transcended into the otherworld, became "yuer", a lost soul that inflicts sickness on people. To prevent her malicious acts, shamans offered her sacrifices. After these events' ancestor Ellei performed an ysyakh, and became a founder of the Ysyakh ceremony. He built a summer dwelling — birch bark urasa covered in patterns. From birch-tree he made vessels for kumiss - choron, ymyia, mataarchack and others. He built a smoky bonfire, too. The myths say that Ellei was the first to perform a custom of lifting up the kumiss cup. It was customary for the people to face east as they raise up the kumiss filled cups, honouring the deity they wanted to address personally (Ksenofontov,1977).

Myth and rituals see death and rebirth face to face. Death is a cardinal event that serves as a ground for new things, and thus death is an essential part in the cycle of restoration. As E. Stroganova writes, "death, real or imaginary, gets its true positive meaning. It prepares new existence, pure spiritual or material rebirth at a higher level." (Stroganove, 2000).

In the above-mentioned myth, Omogoi's favourite daughter dies or transcends to heaven during the preparation and performance of the ysyakh ceremony. There is another version of this myth, in which "two beautiful maidens decided to see Ellei's celebration. They 
became so jealous of their sister's lot, that the elder girl strangled herself and so did the younger, after she uttered, 'I shall be the deity's maiden!' (Historical tales and legends of the Yakuts, 1960).

It is possible that in the past the ysyakh ceremony included essential features of Skythian funeral and commemorative rites, such as drinking kumiss, obligatory meat consumption, and competitions (wrestling, horseracing, archery). It should be highlighted that funeral and commemorative elements in Ysyakh are rather distinctive.

N.B. Dashieva believes that the Buryat main ritual forms go back to funeral and remembrance traditions (Dashieva, 1985).

The "Pattern" dance observes all the elements of the ysyakh ceremony, that is, all the essential components specific to the ysyakh. These components are sports competitions, osuokhay, drinking kumiss, eating meat, etc. It was during the Ysyakh celebration when the Yakuts prayed to the presiding deity Yurung Aar Toyon. Just as the ancient Turki, the Yakuts offered their prayers each year at the beginning of summer (Romanova, 1994).

The dance structure and imagery can be divided into three parts.

Part one. A young girl and a young boy meet each other and fall in love. Bitisiits bless the boy and the girl. The symbolic movements of bitisiits convey the blessing and the wishes of long, happy and prosperous life. The dancers surround the girl and the boy, guarding their happiness, and become their "wings", echoing their love. This episode is accompanied by the directing singer's song that the dancers join in. The first part of the dance talks about a joyful meeting of the young people, about the ancitipcation of happiness. This is the part that contains such movements as "mуос uhum oŭyyma" (tuos uhut oiuuta) - birch bark vessel ornament, "чороон иhит ойуута" (choron uhut oiuuta) - kumiss cup ornament, "тордуйa ункуутэ" (torduia unkuute) - movements imitating the pattern on birch bark vessel called "torduia", and other ornamental movements. 


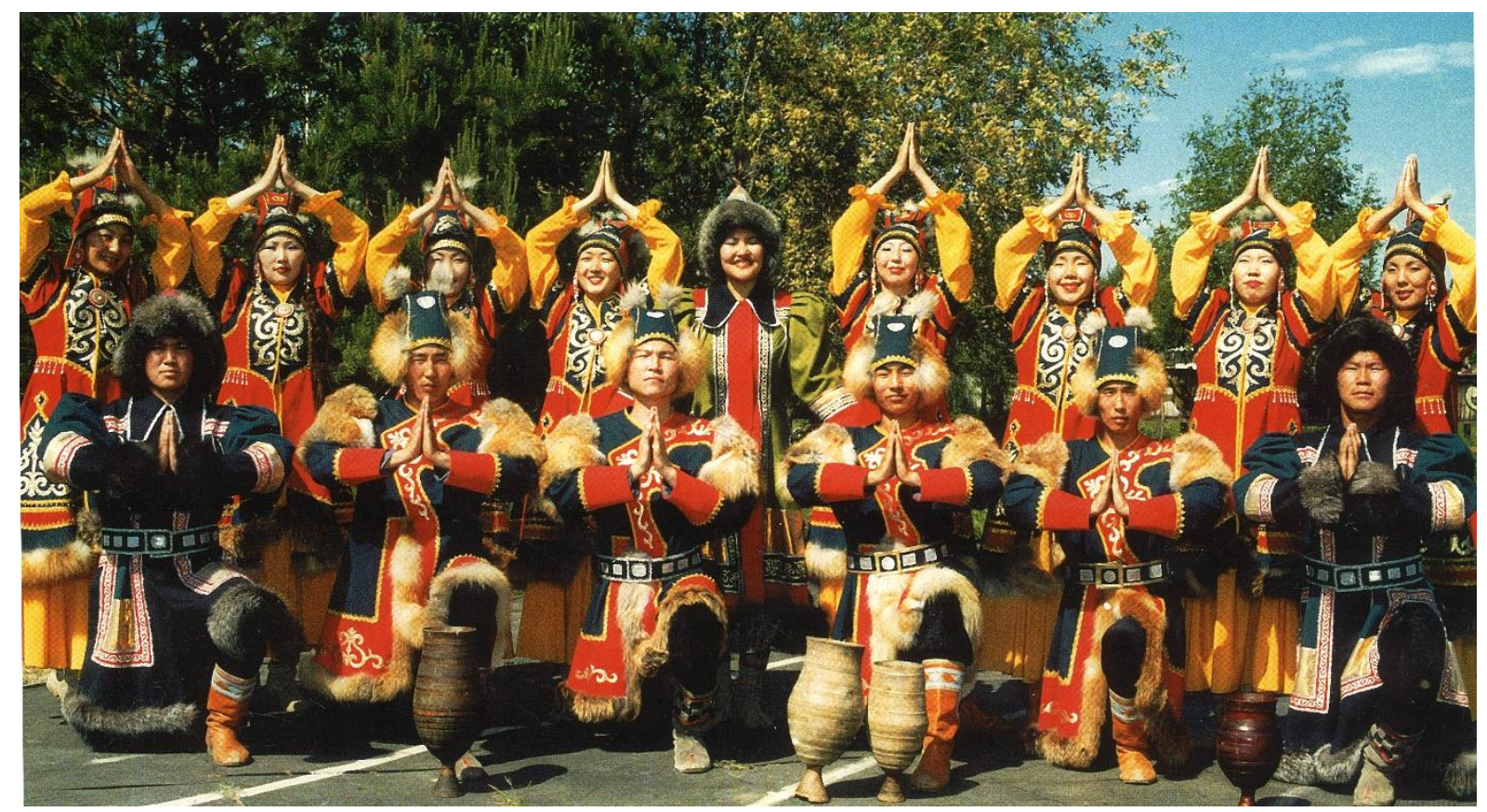

Fig.l. Movements depicting birch vessel patterns.

Part two. Here we see a rendering of a workflow. The bridal gear is being made. Young men make silver jewellery for the bride. Young women make clothes for the bride.

In the second part, the pattern motive is relayed through the movements that imitate work. The movements also remind of patterns that decorate birch bark and wooden vessels.
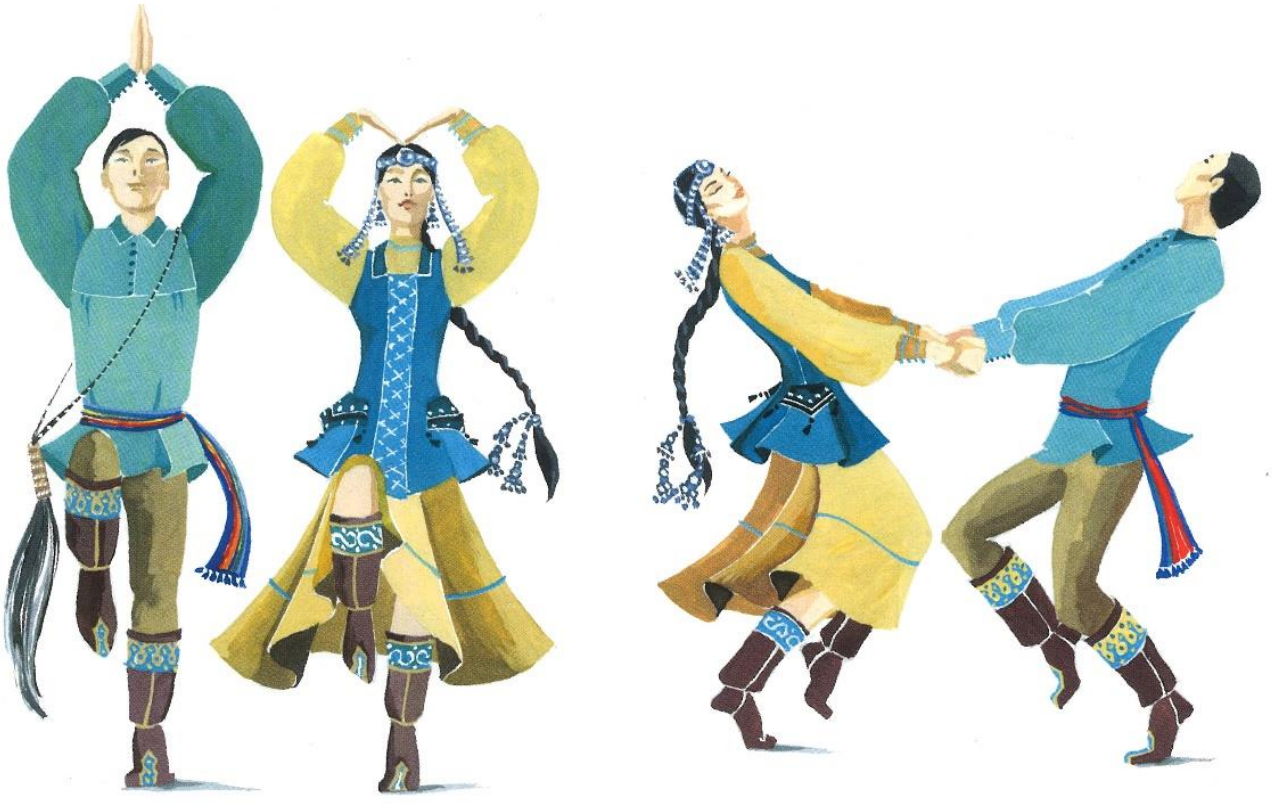

Fig. 2. Ornamental patterns. 
REVISTA DE LA UNIVERSIDAD DEL ZULIA. 3época. Año $12 \mathrm{~N}^{\circ}$ 34, 2021 Angelina Grigorevna Lukina // Yakut Ritual Dance "Pattern”: concepts of life and death, 604-630 DOI: http://dx.doi.org/10.46925//rdluz.34.33

Part three. Everyone rejoices and celebrates the young pair happiness. Yet some motives of funeral and commemoration rite can be still noticed in static hand movements. In general, the cyclically repeating pattern motive of the movements reflects the ornament of birch bark vessels. The pattern that decorated birch bark canvas or sheets - purely ritual attributes, used widely in the past in ritual constructions.

In the third part of the dance the pattern motive persists in such original jumping movements as "тобукхолбоон ойуy" (tobuk kholboon oiuu) - when pairs of dancers jump raising their knees to the waist level, "тилэх тэпсии" (tilekh tepsii) - heel kicks, "таналай уктээн ойуу" (tanalai ukteen oiuu) - leg movements that imitate a pattern observed on a cow palate. This movement represents a ladder that reaches the sky.

Therefore, the pattern motive is woven into all three parts of the "Pattern" dance. In the first part of the dance, the distinctive pattern is mainly created by hand movements. In the second part, the pattern is created with the movements that imitate workflow. In the third part, the pattern motive is less evident, but can still be found, especially in leg movements.

In regards to plot, the "Pattern" dance consists of three parts, as was shown above. Insofar as choreographic imagery is concerned, there are two parts - worldly and ritual, i. e., one part deals with images depicting life events such as lovers' date, competitive games, ysyakh scenes, work process, while the other reflects ritual meaning through static movements. The "Pattern" dance brings these two layers of imagery together. Still, the movements that depict joy of life dominate in the dance. The set of choreographic images that show the aspects of happy life is richer and more diverse. The idea of a perpetual life prevails, even though the unbreakable connection between life and death, destruction and creation, beginning and end, is apparent in the "Pattern" dance. In general, traditional and ritual Yakut dances have more movements that celebrate life and its bright sides. The quintessence of the "Pattern" dance is the upbeat movements, symbols, gestures and pas that epitomize life.

Each pattern movement has its meaning, each movement can be deciphered. Patterns created with hand movements resemble traditional Yakut ornaments. There is nothing unfamiliar here nor coincidental. It is known that the origins of Yakut ornaments date back centuries, and reflect key concepts of mythic consciousness. 
In the past, patterns acted like a talisman, performing protective and purifying functions. The "Pattern" dance choreographic imagery represents all the main motives of Yakut pattern, such as "koguor oiuu", a lyre-shaped ornament for prosperity and fertility. As a vegetal pattern, "koguor oiuu" stands for buds, shoots, flowers, and revelry of life.

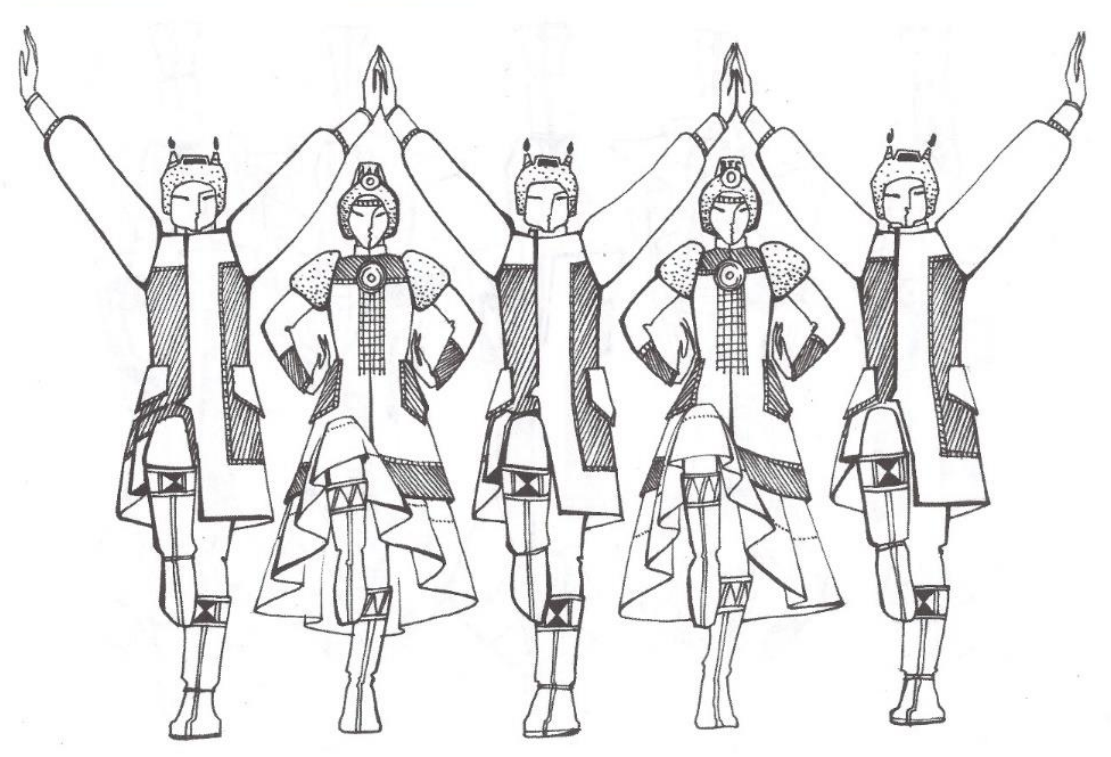

Fig. 3. Fertility ornament.

The patterns created by dancers-bitisiits - "буор ойуy" (buor oiuu, or bud-pattern), "сюрэх ойуу" (surekh oiuu, or heart-pattern) - are the symbols of life.

The movements of the "Pattern" dance display vitality. Arm position called "дугалыы oŭyy" (dugalyy oiuu) is an imitation of an arc-shaped pattern which signifies the open sky. Arms raised high and shaping an oval represent the arc of the sky.

The ritual hand movement "kuruo oiuu" (or fence-pattern) symbolises a fence that protects the living from evil. This pattern movement is a talisman for protection. The dancers make with their hands and arms zigzag, triangular, wave-like and brace-like movements, associated with elements of ancient Yakut ornament which stands for protective forces.

Such symbolic gestures and meaningful pas relay an encrypted message. These pattern movements have a deep semiotic meaning. In fact, each pose, each movement is a thought translated into dance.

The "Pattern" dance is a sort of choreographic sacrifice for the dead girl. It gives the girl her life that she did not get to live through, in a stylised, imaginary form. Instead of a life 
REVISTA DE LA UNIVERSIDAD DEL ZULIA. $3^{a}$ época. Año $12 \mathrm{~N}^{\circ}$ 34, 2021 Angelina Grigorevna Lukina // Yakut Ritual Dance "Pattern": concepts of life and death, 604-630 DOI: http://dx.doi.org/10.46925//rdluz.34.33

that ended prematurely the girl receives the "Pattern" dance with a life-asserting beginning and a happy finale. Thus, she gets a compensation for the cancelled life. Accepting this sacrifice, the girl can no longer remain angry with her lot. This is why the idea of life and optimistic motives are so strongly represented in the dance and why the dancers do not show grief or sorrow. The dance shows all the most important moment in one's life: the birth of love, marriage, happy existence, rewarding labour, optimistic scenes of the ysyakh ceremony, sports competitions, feast, joy and excitement. The dance movements are exaggeratedly upbeat and elated, with intensive emotions and energy. There is not a moment of sadness in the dance. The performers are in high spirits. Only momentary elements in the patterns that performers draw with their hands, remind of the fate and the story behind the dance origin. Everything about the dance - its composition, style of performance, emotional intensity, movements, face expressions - expresses the triumph of hope. There is much in the dance that celebrates life. It is painted as exuberant and joyful with the episodes of young people meeting and falling in love, of the holiday blessing, competitions and labour. The dancers imitate the acts of making silver jewelry for the bride - they pump the bellows, hammer and file the metal, they sew, spin the thread and twist the rope. Thee show work. They also show competitive sports which can be seen at the Ysyakh: young men wrestling, stick pulling, along with elements of heroic games.

"Pattern" is one of the most mysterious, perhaps even paradoxical dances reflecting the worldviews and world perception of the ancient Yakuts. Even the hand movements that were cyclical and repeated periodically stood for representation of life events. For example, arm position "дугалыы ойуу" (dugalyy oiuu), or the arc, symbolises the arc of the sky; palms joined above one's head "ураса ойуy" (urasa oiuu), or yurta-pattern) in a triangle represented a birch bark yurt; with bent arms and hands touching the temples, performers displayed cow horns (horn-pattern). There exists another variant of this movement when performers put their fingers to their shoulders. Raised arms and hand with palm facing up represented "koguor oiuu", lyre-shaped pattern depicting vegetation. The dancers moved their hands a zigzag pattern, reminiscent of that put on wooden and birch bark vessels. With arms raised and elbows bent, they evoked the image of a fence. Using various patterns, performers of the "Pattern" dance spoke of happy life. The movement imitating cow horns symbolised wealth. Turkic peoples used curled horns pattern as a sign of wealth and prosperity (Kenzikeev, 
2018). The dance using choreographic images talks about a girl called Ohyop Tyoc (Ohuor Tuoc) who lived a happy life, with a nice house and uraha (yurt), a loving fiancé, and a big close-knit family, lots of cattle she had grazing behind her fence, so she lived her life without a care under the clear arc of the sky; her house was a wealthy one, with vessels and plates always full of food, and at all times beautiful nature was around her (flowers, trees, grass), so the girl enjoyed her life fully. This praise for happy and trouble-free earthly existence is seen in wonderful ornament-like movements that are associated with the happiest moments of life.

It is no coincidence that the "Pattern" dance combines funeral and remembrance elements with those of ysyakh - a new year celebration connected to the idea of renewal, rebirth and creation. It was for good reason that S.A. Zverev in his letter to M.Ya. Zhornitsaka wrote about the "Pattern" dance that it was a dance of the origin of human life (киһи уоскуурун туһунан ункуу) (kihi uoskuurun tuhunan unkuu) (YNC SO RAN 1949).

One of the major meaning-making gestures in the dance is palms pressed together. A gesture symbolises prayer, concordance, gratitude and peace. It is the centrepiece of all patterns in the "Pattern" dance. A fundamental gesture that gives rise to the variety of ornamental movements. It has a compound meaning.

This gesture represented the love of the udagan for her daughter, the love of groom to his bride, the love for live, and harmony and bliss, unity with nature, respect for other people; in some sense, reconciliation with fate and its acceptance. There is no doubt that it is originally a religious gesture performed when addressing deities. It is a gesture of praying, pleading, forgiving. It is possible that the ancient Sakha people used it during their prayers to aiyy deities. It helped to focus attention as it was directed to the Upper world, the world of deities. Concentration, introspection, calmness, reflection, - there are the meanings behind a deeply religious gestures that serves as a core of the "Pattern" dance choreographic imagery. 


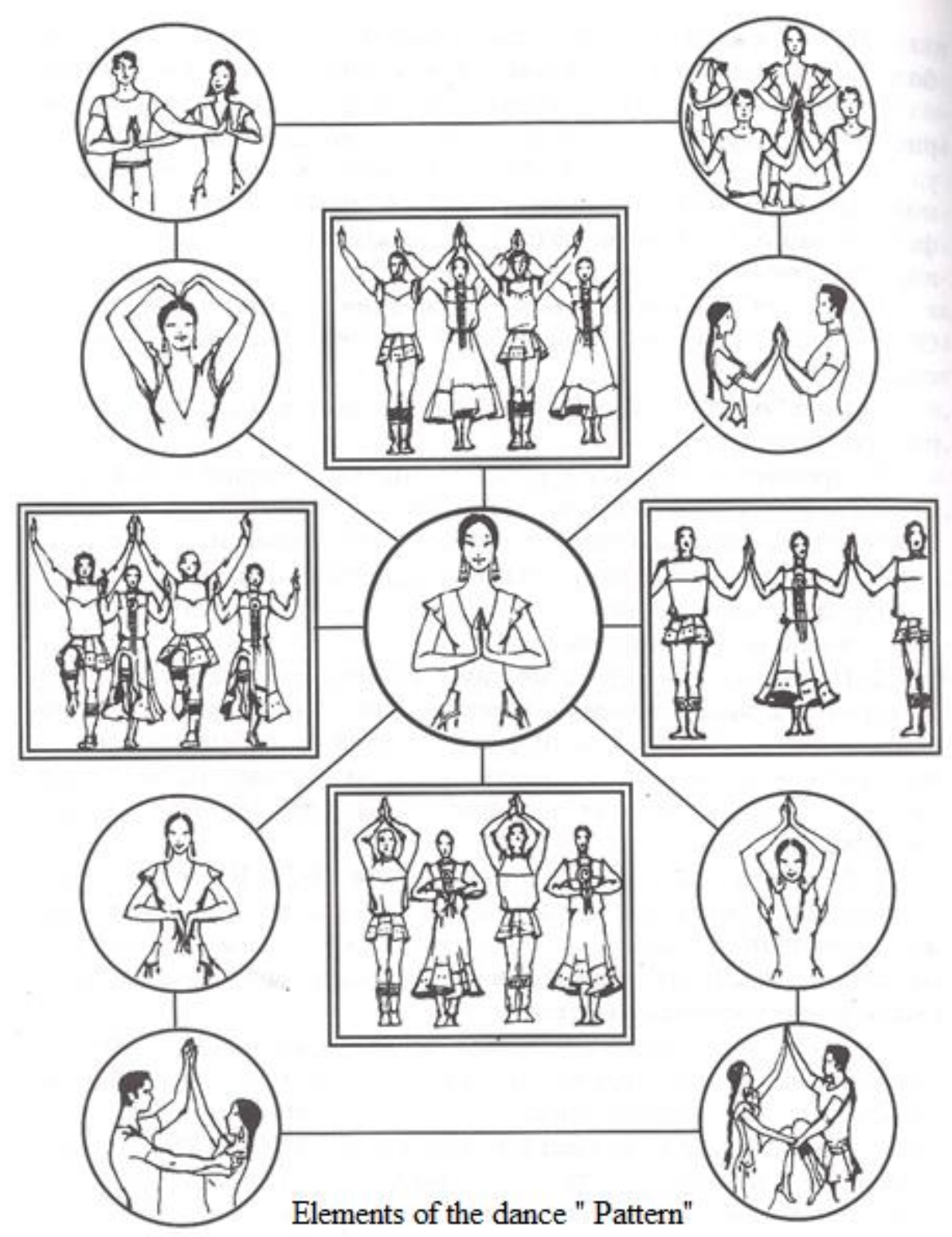

Fig. 4. Blessing gesture.

Traditional Yakut dances have always had a dormant desire to unite dance with prayer. For the Yakuts, dance, or "ункуу" (unkuu) has tradinitally meant praying and was a dedication to aiyy deities - "айыыларга анаммыт" (aiyylarga anammyt). Such conceptual approach reflects the depth of vision in folk art, innermost thoughts from encrypted and encoded symbols iof archaic culture, including dance culture of the world. This level of perception and understanding helped to create certain forms and symbols of ritual choreography, telling about life and death, the three worlds, flight to the Upper world, etc. A performer of a ritual dance would always feel a strong desire to break the barrier 
between the three worlds, between sacred and mundane. Traditional Yakut dances are seamlessly included into a religious belief system where kinetic and dance symbols are seen as means of reaching, on a mystic level, a contact with aiyy deities, with иччи (ichchi), spirits that guard the barrier. The ancient Yakuts believed it possible to initiate a two-way communication, a dialogue between the dwellers of three worlds.

The prayer gesture is a keynote of the "Pattern" dance.

Once cannot but recall the movement from this dance called "дугалыы ойуу" (dugalyy oiuu), the arc of the open sky. The sky for the Yakuts is a place where aiyy-deities dwell.

One of the oldest movements in Yakut ceremonies is "таналай уктээһин" (tanalai uktehin), i. e. a step called таналай is imprinted with "таналай ойуу" (tanalai-oiuu, skypattern). Dancers move their leg and feet in such a way that allows them to draw an image resembling a pattern of a cow palate. In Yakut ritual practices, this movement represents a ladder going into the sky. The pattern made by treading the sky imagery represents moving up that ladder. In the "Pattern" dance this leg movement signifies the sky road which takes the soul of the dead girl to heaven. This "tanalai ukteehin" movement symbolises the road connecting the sky and the earth. It is not by chance that this movement is performed late in the dance, when the dancers lift the girl's "kut" — soul — into the sky. This archaic ritual movement affirms the purpose of the dance.

Its reproduction of a sky-pattern objectifies, with the use of activity approach, the sky road on which the souls of the dead ascend (Struchkova, 2005). The "Pattern" dance serves as a means of separating the dead girl's soul from the living and lifting it up into the sky. This is why, perhaps, the dance is performed in such an upbeat, almost ecstatic tempo that takes everyone higher. The speed of movements is intensified by vertical jumps. It should be noted that identical positions of legs and bodies are pictured on rock paintings at the Lena River and the Olyokma River.

The finale of the dance, where its quintessence becomes evident, is naturally determined. During the finale, the dancers perform the third part of the dance, the fast part of the traditional circle dance osuokhay — ascension in the form of "булуулуу ohyохай" (buluuluu ohuokhay), or the Vilyuisk osuokhay. The jumping part of osuokhay is performed - $к о т y$ (kotu), or ascension. The dancers form a circle and quickly move leftwards, sunwise. 
REVISTA DE LA UNIVERSIDAD DEL ZULIA. 3época. Año $12 \mathrm{~N}^{\circ}$ 34, 2021 Angelina Grigorevna Lukina // Yakut Ritual Dance "Pattern”: concepts of life and death, 604-630 DOI: http://dx.doi.org/10.46925//rdluz.34.33

This energetic movement performed in a circle contains the idea of how all the dancers work together to help lift the soul of the dead girl. In relation to the plot-depicting actions, at this point "кут котогуутэ" (kut kotoguute), or the lifting of the girl's soul, takes place. With these ritualistic movements, which represent the soul's departure for the heavens, the "Pattern" dance ends. The above statement indicates that content and meaning of the dance moves are identical to the worldviews of the ancient Turkic people and to their concepts of life and death. As R.I. Bravina writes: "in the ancient Turkic accounts, 'to die' is conveyed through 'to fly away', 'to depart', which can be compared to Yakut sayings "Kyma кonnym" (kuta kopput) - 'soul has flown away', "кута барда" (kuta barda, "soul has gone away", and "кута аттанна" (kut attanna), 'soul has departed'." (Bravina, 1996).

The ritual dance "Pattern" comes to its logical conclusion in these movements and becomes complete. However, a circle is also a symbol of returning life. The dance idea vision is that the "flying" sun circle of osuokhay dance goes through a ritualistic death towards rebirth. The circle that moves quickly sunwise, in fact, restores life force, brings back life and draws everyone into the circle of life (Lukina, 2020). So, the archaic tragic story of saying goodbye to an untimely deceased young girl when performed as a dance transforms into a celebration of life. This is a unique case in the folk art, when one idea changes into another, more powerful and vital. Through a metamorphosis of consciousness, a ritual dance becomes a way to manifest life despite of death. In this regard, the "Pattern" dance signifies the return of life, of one's vital force. When human energy unites with cosmic rhythms, quantum leap happens - a return of life. It happens through an understanding of inner dramatic nature pertaining to the connection between life and death, where the force of life prevails over death every time. The ritual dance "Pattern" shows how one for the sake of life can cope with the idea of death.

The dance preserves unique movements emphasizing the idea of life. It is essential that the "Pattern" dance holds a special place in the Yakut dance culture. Traditional dances of the Evens, the Evenks, the Chukchi, the Yukaghirs and other indigenous small-numbered peoples of the North and Northeastern Siberia have no dances analogous to the "Pattern". The ritual dance "Pattern", as well as the traditional circle dance osuokhay, date back to ancient Turkic traditions. These two dances, "Pattern" and osuokhay, are related to ancient Turkic commemorative rites and ancestor worship, same as the ancient Yakut ceremony of 
REVISTA DE LA UNIVERSIDAD DEL ZULIA. 3época. Año $12 \mathrm{~N}^{\circ}$ 34, 2021 Angelina Grigorevna Lukina // Yakut Ritual Dance "Pattern”: concepts of life and death, 604-630 DOI: http://dx.doi.org/10.46925//rdluz.34.33

ysyakh. The ritual dance "Pattern" belongs to the layer of ancient Turkic worldviews and beliefs. The Yakuts are the northernmost Turkic-speaking population, who have preserved ancient forms of folk art, such as ysyakh, ritual and commemorative rites, and the ritual dance "Pattern", all of which are connected to the ancient Turkic culture (Lukina, 2019).

Since identical hand movements can be seen in Buryat, Tuvinian and Mongolian dances, it indicates that the "Pattern" dance has clear signs of eastern nature.

The conclusions of the author of the article are confirmed by scientific developments of the first researcher of the traditional dance culture of indigenous peoples of North M.Ya. Zhornitskaya (Zhornitskaya, 1960). The motifs characteristic of the mythological traditional worldview of the Yakuts are consonant with the author of this article and are recorded in the work of scientist N.A. Struchkova (Struchkova, 2008).

Conclusion

The "Pattern" dance is an archaic ritual dance. This is corroborated by the fact that this dance has strong connections to archaic funeral rites.

In this dance, the following functions of the ancient Yakuts' ritual actions can be clearly observed:

1. Help the dead to reach the afterlife. Recompense the untimely deceased for the life that did not get to live, by the means of a dance.

2. Protect the living from the possible influence of the dead by mollifying them with sacrifices. In this case, the "Pattern" dance is the sacrifice that was given to the dead girl in place of her might-have-been long and happy life.

3. A movement called "таналай котуу" (tanalai kotuu) represents a ladder that reaches the sky and the lifting of "kut", dead person's soul, into the Upper world. A similar notion exists in fast-paced osuokhay jumps that also symbolise "ascension" or "flight".

The above statement indicates that content and meaning of the dance moves are identical to the worldviews of the ancient Turkic people and to their concepts of life and death. As R.I. Bravina writes: "in the ancient Turkic accounts, 'to die' is conveyed through 'to fly away', 'to depart', which can be compared to Yakut sayings “кута коппут” (kuta kopput) - 'soul has flown away', "кута барда" (kuta barda, "soul has gone away", and "кута аттанна" (kut attanna), 'soul has departed'.” 
REVISTA DE LA UNIVERSIDAD DEL ZULIA. 3época. Año $12 \mathrm{~N}^{\circ}$ 34, 2021

Angelina Grigorevna Lukina // Yakut Ritual Dance "Pattern”: concepts of life and death, 604-630

DOI: http://dx.doi.org/10.46925//rdluz.34.33

This is exactly what happens in the "Pattern" dance: "куm котуymэ (kut kotuute), the raising or lifting the soul of the dead girl by using ritual jumping movements «таналай уктээн котуу» (tanalai ukteen kotuu) and «котуу» (kotuu) in the final circle osuokhay.

In summary, based on the analysis of the dance structure, significance of dance movements, plastique, content and imagery, the following conclusions can be reached:

1. The origins of the ritual dance "Pattern" go back to spiritual traditions of the ancient Turkic peoples.

2. The ritual dance "Pattern" has strong connections to archaic funeral rites, the most conservative manifestations of views on life and death.

3. The ritual dance called "Pattern" reflects the most archaic meaning of ysyakh ceremony which was tied to the idea of renewal and rebirth, and included essential elements of funeral and commemorative Yakut rites. The old form of ysyakh ceremony dates back to rites of remembrance dedicated to ancestors and it shows features of traditional culture of ancient cattle-breeding peoples, which are connected to the idea of the return of life.

4. Sacred dancers "bitisiits" participated in all major rituals and ceremonies of the Yakuts. They participated in ysyakh ceremony and in remembrance rites that dealt with concepts of life and death and ideas of rebirth and renewal.

5. The ritual dance "Pattern" belongs to the layer of ancient Turkic worldviews and beliefs. This is especially evident in the structure of the ancient Yakut ceremony - ysyakh. The elements of ysyakj are preserved in the ritual dance "Pattern".

6. The activity dimension of the dance has a ritual action called "кут котутуy" (kut kotutuu), i. e. the lifting of the dead person's soul, which is consistent with ancient Turkic ideas of life and death. Movements such as "таналай уктээһин" (tanalai ukteehin) or "таналай уктээн коту" (tanalai ukteen kotu) are connected to the ancient Turkic traditions of soul ascension.

7. The "Pattern" dance dates back centuries. This is reflected in the meaning of a crucial ritual gesture - "hands put together". This prayer gesture is one of the lost elements of archaic choreography related to religious beliefs. The "Patten" dance, based on an ancient story, develops and enriches this gesture as it combines dance and prayer. 
REVISTA DE LA UNIVERSIDAD DEL ZULIA. 3época. Año $12 \mathrm{~N}^{\circ}$ 34, 2021 Angelina Grigorevna Lukina // Yakut Ritual Dance "Pattern”: concepts of life and death, 604-630 DOI: http://dx.doi.org/10.46925//rdluz.34.33

8. The "Pattern" dance reflected numerous essential ideas of life and death that came from the ancient Yakut rituals and traditions. Ritual dances, included into a complex part of ceremonies, acted as independent symbolic units reflecting the concepts of life and death.

9. The quintessence of the "Pattern" dance is the triumph of life. Here the archaic tragic story of saying goodbye to an untimely deceased young girl, performed as a dance, transforms into a celebration of life. The dance metamorphoses the concept of death into the concept of life. Through a metamorphosis of consciousness, a ritual dance becomes a way to manifest life despite of death. The ritual Yakut dance "Pattern" signifies the return of life, of one's vital force. It is the celebration of life, a choreographic hymn to life.

10. The dance embodies life, but life has in it the idea of fate.

11. Pas and symbolic movements of the dance reflect the idea of eternal life, of the circle of life and constant rebirth.

Because of its connection to elevating a deceased to a venerable ancestor, the "Pattern" dance acquired a certain festive and solemn mood, which explains its energetic and upbeat performance. There is hardly anything paradoxical now in a combination of sadness and joy, of a tragic event and an optimistic start. The idea of life, represented in the dance life, contains the idea of fate. All the movements of the dance along with its composition express the joy of exuberant life; the vivid image of it is present in in the plot and in the particular mood of the performers. Still, sometimes, in cyclical and repeated periodically static hand movements, in geometrically strict patterns one can see the reminders of fate, death and unbeing. They are cold undertones of inevitability, of repeatability of life and death.

However, in the end the "Pattern" dance displays exaggerated vivacity and optimism. The dance serves as a hymn to life performed with choreographic movements. A common thread running through this upbeat dance is an idea of continuing life, of procreation and the circle of life, the main idea of the dance is that life goes on without end,

The peak of the "Pattern" dance is the circle dance osuokhay, which can be seen as a dance hymn to life. In general, the ritual dance "Pattern" actualizes key concepts of life and death.

\section{References}

Bongard-Levin G.M. (1980). Ancient Indian Civilization: Philosophy, science, religion. Moscow, Nauka Publ., P.16. 


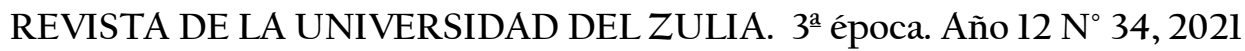
Angelina Grigorevna Lukina // Yakut Ritual Dance "Pattern”: concepts of life and death, 604-630 DOI: http://dx.doi.org/10.46925//rdluz.34.33

Bravina R.I. (1996). Funeral rite of the Yakuts (17-19th centuries). - Yakutsk, Bichik Publ., P. 40.

Bravina R.I. (1996). Funeral rite of the Yakuts (17-19th centuries) - Yakutsk, Bichik Publ. P. 120.

Dashieva N.B. (1985). Traditional community celebrations of the Buryats. A historical and ethnographical study. Extended abstract of Cand. Of Hist. Sc. dissertation - Moscow, P.13.

Ergis G.U. (1974). Essays on Yakut Folklore. - Moscow, Nauka Publ., P.108.

Historical tales and legends of the Yakuts (1960). - Moscow, Leningrad, Publishing House of the Academy of Sciences of the Soviet Union, V. 1-2, P. 58.

Ksenofontov G.V. YNC SO RAN Archive. Coll. 4, Aids 1, P. 102; Coll. 4. Aids 12, Item 48.

Konstantinov I.V. (1971). Material culture of the Yakuts in the 18th century. (Based on the materials from the burials). Yakutsk. Yakutsk National Publishing House, P. 38.

Klark. P.E. (1864). Vilyuisk and its district (Yakuts domestic life and statistics) // Notes of the East Siberian Department of the Imperial Russian Geographical Society. - Siberian Department of the Imperial Russian Geographical Society, Book 7, pp. 91-165.

Kyys Debiliye (1993). Yakut heroic epic. - Novosibirsk, Publishing House "Nauka" SB RAS, P. 275.

Ksenofontov G.V. (1977). Elleiada. - Moscow, Nauka Publ, pp. 29-50.

Kenzikeev R.V. (2018). Direction and scenic interpretation of traditional dances of the Turkic people of Kazakhstan. - PhD dissertation. Kazakhstan, Almaty, P. 38.

YNC SO RAN (1949). Archive. Coll. 5, Aids 9, Item 45. Records by S.A. Zverev from 1.12.

Lukina A.G., Doktorova N.I. (2013). Yakut epic: kinetics and clothes. - Novosibirsk: Nauka Publ., pp.152, 133.

Lukina A.G. (2020). Angelina Lukina. Osuokhai, The Yakut Circle Dance // Sibirica: Interdisciplinary of Siberian Studies. - Vol. 17, №3- P. 60-67. ISBN 1361-7362 (Print), ISSN 1476-6787 (Online). DOI: https://doi.org/10.3167/sib.2018.1

Lukina A. (2019). Worldview foundations of Yakut ritual dance "bitii". Amazonia Investiga, $8 \quad$ (24), 162-169. $\quad$ Retrieved from https://amazoniainvestiga.info/index.php/amazonia/article/view/968.

Mircea Eliade (1999). A History of Religious Ideas. Volume 1. - Saint Petersburg: Aleteya Publ., P .210.

Romanova E.N. (1994). The Yakut Holiday of Ysyakh: Origins and Concepts. Novosibirsk, Siberian Publishing Company "Nauka", P. 53. 
REVISTA DE LA UNIVERSIDAD DEL ZULIA. 3época. Año $12 \mathrm{~N}^{\circ}$ 34, 2021 Angelina Grigorevna Lukina // Yakut Ritual Dance "Pattern”: concepts of life and death, 604-630 DOI: http://dx.doi.org/10.46925//rdluz.34.33

Stroganove E. (2000). Mircea Eliade // M. Eliade. Aspects of myth. - Moscow, Akademichecky Prospekt Publ., P. 191.

Struchkova N.A. (2005). Formation of the kinetic component in ritual practice. Saint Petersburg, SPbGU publishing, pp. 186-187.

Struchkova N.A. (2008) Olonkho and foundations of kinetic culture of the Sakha People Novosibirsk, "Nauka", pp. 67, 86.

Yakutsk National Centre (1936-1941). Yakutsk National Centre of the Siberian Department of The Russian Academy of Sciences (YNC SO RAN) Archive. Coll.4, Aids 12a, Item 19, pp. 207, 127; Coll. 4 aids 12, item 19; Coll. 4, aids 12, fol. 19. Funeral rites of the peoples of the North.

Zhornitskaya M. Ya. (1960) Folk dances of Yakutia. Moscow, "Nauka", pp. 83 - 84, 131, 141 142 